\title{
PENGUNGKAPAN ASET BIOLOGIS PADA PERUSAHAAN ALGIKULTUR DI INDONESIA SERTA FAKTOR YANG MEMPENGARUHINYA
}

\author{
Hesty Erviani Zulaecha ${ }^{1 *}$,Dewi Rachmania ${ }^{2}$, Aeling Setya Amami ${ }^{3}$ \\ ${ }^{123}$ Universitas Muhammadiyah Tangerang \\ ${ }^{1}$ Hestyerviani2005@gmail.com, ${ }^{2}$ dewi.rachmania78@gmail.com, ${ }^{3}$ Aelingsetya@gmail.com
}

\begin{abstract}
ABSTRAK
Penelitian ini bertujuan untuk menguji dan menganalisis Pengaruh Biological Asset Intensity, Ukuran Perusahaan dan Kepemilikan Manajerial terhadap Pengungkapan Aset Biologis Pada Perusahaan Agrikultur Sub Sektor Perkebunan Yang Terdaftar di Bursa Efek Indonesia (BEI). Periode waktu penelitian yaitu 2015-2019. Populasi yang digunakan dalam penelitian ini yaitu perusahaan agrikultur yang terdaftar di Bursa Efek Indonesia (BEI) periode 2015-2019. Data yang digunakan dalam penelitian ini adalah data sekunder yang berupa data kuantitatif dari laporan keuangan perusahaan agrikultur yang terdaftar di Bursa Efek Indonesia (BEI) periode 2015-2019. Sampel penelitian terpilih sebanyak 8 perusahaan diperoleh dengan menggunakan teknik purposive sampling. Metode analisis yang digunakan dalam penelitian ini yaitu menggunakan analisis regresi data panel dengan menggunakan program E-Views 9. Hasil penelitian menunjukkan bahwa biological asset intensity dan ukuran perusahaan berpengaruh positif terhadap pengungkapan aset biologis, sedangkan kepemilikan manajerial tidak berpengaruh terhadap pengungkapan aset biologis.
\end{abstract}

Kata Kunci : Aset Biologis, Biological Asset Intensity, Ukuran Perusahaan, Kepemilikan Manajerial, Pengungkapan Aset Biologis.

\section{PENDAHULUAN}

Kawasan Asia Tenggara merupakan kawasan tropis yang memiliki banyak sumber daya alam yang melimpah. Indonesia termasuk ke dalam kawasan tropis dan sebagian masyarakatnya bermata pencaharian sebagai petani atau bekerja dibidang agrikultur. Indonesia menghasilkan komoditas ekspor dibidang pertanian dan perkebunan. Jika dilihat dari potensi sumber daya alamnya, Indonesia seharusnya mampu untuk memenuhi kebutuhan pangan bangsanya dan mengurangi kegiatan impor hasil pertanian. Oleh sebab itu, sektor agrikultur harus terus dikembangkan karena sektor tersebut sangat penting dalam menunjang perekonomian di Indonesia. Pada Sektor agrikultur berupa tanaman perkebunan dan peternakan memiliki karakteristik khusus yang membedakan dengan sektor lainnya, yang ditunjukkan dengan adanya aktivitas pengelolaan dan transformasi biologis atas tanaman untuk menghasilkan produk yang akan dikonsumsi atau diproses lebih.
Di Indonesia saat ini ada beberapa perusahaan agrikultur mulai berkembang tetapi belum banyak yang dapat mengungkapkan aset biologisnya sesuai PSAK 69. Merujuk pada hasil penelitian Hariyanti, dkk (2018) ada tiga kasus perusahaan agrikultur tahun 2018 pada akhir periode telah mengukur asset biologisnya dari harga perolehan menjadi harga wajar dan telah mengungkapkan deskripsi asset biologis. Ketiga perusahaan tersebut yaitu PT Eagle High Plantation, Tbk, PT Dharma Satya Nusantara, Tbk., dan PT Gozco Plantation, Tbk. Namun dari ketiga perusahaan tersebut, hanya satu perusahaan yaitu PT Gozco Plantation, Tbk yang pada akhir periode telah mengukur asset biologisnya dari harga perolehan menjadi harga wajar dan telah mengungkapkan mengapa nilai wajar dapat diukur secara andal serta telah mengungkapkan dampak dari perubahan tersebut. Sedangkan dua perusahaan lainnya yaitu PT Eagle High Plantation,Tbk, PT 
Dharma Satya Nusantara,Tbk., tidak mengungkapkannya. Kasus lain adalah pada penelitian Kirana (2019), PT Perkebunan Nusantara X di Surabaya pada bulan September 2018 tidak mengukur nilai wajarnya karena kebijakan yang ditetapkan adalah menggunakan konsep biaya perolehan. Sehingga perusahaan harus memberikan pengungkapkan-pengungkapan tambahan tersebut. Perusahaan sudah memberikan deskripsi atas aset biologis yang dimiliki dalam suatu naratif atau deskripsi, namun mereka tidak menjelaskan penjelasan tentang mengapa alasan nilai wajar tidak dapat diukur secara andal. Perusahaan hanya mengungkapkan bahwa dalam pengukurannya menggunakan konsep biaya perolehan dan mengungkapkan bahwa nilai tanaman semusim merupakan beban produksi. Perusahaan tidak mengungkapkan keuntungan atau kerugian atas tanaman karena perusahaan tidak melakukan pencatatan atas keuntungan atau kerugian tanaman, serta tidak melakukan penyusutan terhadap tanaman sehingga tidak mengungkapkannya.

Apabila sebuah perusahaan memiliki nilai aset biologis yang tinggi, maka tingkat pengungkapan asset biologisnya akan meningkat hal ini akan menarik perhatian investor untuk menanamkan modalnya. Ukuran perusahaan, menunjukkan bahwa semakin besar perusahaan maka semakin tinggi pula tuntutan terhadap keterbukaan informasi dalam pengungkapan aset biologisnya dibanding dengan ukuran perusahaan yang lebih kecil. Kepemilikan manajerial dapat menjadikan perusahaan berkembang dan memiliki kinerja yang baik. Dengan adanya kepemilikan manajerial kecil kemungkinan terjadi konflik kepentingan antara manajer dengan pemegang saham. Perusahaan yang berkembang dan memiliki kinerja yang baik akan semakin banyak mengungkapkan informasi aset biologisnya, dengan begitu akan mengundang investor untuk menanamkan modalnya. Penelitian sebelumnya oleh (Goncalves \& Patricia, 2014; Yurniwati et al., 2018) memperoleh hasil bahwa intensitas aset biologis berpengaruh positif signifikan terhadap pengungkapan aset biologis. Sedangkan pada penelitian Sa'diyah,dkk (2019), menunjukkan hasil yang berbeda bahwa biological asset intensity berpengaruh negatif signifikan terhadap pengungkapan aset biologis. Pengujian pengaruh ukuran perusahaan terhadap pengngkapan aset biologis pada penelitian sebelumnya oleh (Goncalves \& Patricia, 2015; Yurniwati dkk., 2018) memperoleh hasil bahwa ukuran perusahaan berpengaruh positif signifikan terhadap pengungkapan aset biologis. Namun demikian hasil penelitian Alfiani \& Rahmawati (2019) dan Putri (2019) menyatakan sebaliknya bahwa ukuran perusahaan tidak berpengaruh terhadap pengungkapan aset biologis. Hasil penelitian Alfiani \& Rahmawati (2019) menunjukkan hasil bahwa kepemilikan manajerial pada berpengaruh positif terhadap pengungkapan aset biologis. Sedangkan penelitian Duwu, dkk (2018) dan Putri, dkk (2019) menunjukkan hasil yang belawanan yaitu tidak berpengaruh terhadap pengungkapan aset biologis.

\section{KAJIAN PUSTAKA DAN PENGEMBANGAN HIPOTESIS Pengaruh Biological Asset Intensity terhadap Pengungkapan Aset Biologis}

Menurut PSAK (69) biological asset intensity (intensitas aset biologis) merupakan jumlah proporsi investasi pada aset biologis perusahaan agrikultur yang disajikan dalam catatan atas laporan keuangan. Biological asset intensity pada perusahaan agrikultur menggambarkan besaran proporsi investasi yang dimiliki perusahaan terhadap aset biologisnya. Menurut Duwu (2018) dalam penelitiannya, biological asset intensity (intensitas aset biologis) menggambarkan seberapa besar proporsi investasi perusahaan terhadap aset biologis yang dimiliki. Intensitas aset biologis juga mampu menggambarkan ekpektasi kas yang akan diterima jika aset tersebut kemudian dijual. Artinya semakin tinggi intensitas aset biologis perusahaan, maka semakin besar juga dorongan untuk mengungkapkan informasi yang lebih lengkap dan rinci terkait aset biologis yang dimilikinya. Hal ini merupakan bentuk 
pelaporan perusahaan agrikultur atas aset utama yang dimiliki dan dikelola serta merupakan sumber laba bagi perusahaanperusahaan pada sektor agrikultur. Berdasarkan teori-teori yang telah diuraikan diatas mengenai pengaruh biological asset intensity terhadap pengungkapan aset biologi dapat disimpulkan bahwa intensitas aset biologis merupakan besarnya tingkat investasi suatu perusahaan dan memberikan gambaran mengenai nilai aset biologis pada saat pengungkapannya dalam laporan keuangan.

Hasil penelitian Yurniwati,dkk (2018) menunjukkan hasil bahwa biological asset intensity berpengaruh positif terhadap pengungkapan aset biologis, sejalan dengan hasil penelitian Amelia, penelitian Duwu, dkk (2018) juga memperoleh hasil bahwa biological asset intensity berpengaruh positif terhadap pengungkapan aset biologis.

$\mathrm{H}_{1}$ : Biological Asset Intensity berpengaruh positif terhadap Pengungkapan Aset Biologis

\section{Pengaruh Ukuran Perusahaan terhadap Pengungkapan Aset Biologis}

Ukuran Perusahaan adalah suatu skala dimana dapat diklasifikasikan besar kecilnya perusahaan menurut berbagai cara antara lain dengan total aset, nilai pasar saham, penjualan dan lain lain (Hery 2017). Putri \& Siregar (2019) semakin besar perusahaan semkain dituntut untuk lebih banyak mengungkapkan aset biologis yang ada di dalam perusahaannya. Artinya, semakin besar ukuran perusahaan maka perusahaan cenderung akan lebih banyak mengungkapkan aset biologis yang ada di dalamnya. Sehingga pengungkapan informasi yang lengkap dan rinci diperlukan oleh para pemangku kepentingan karena dengan mengungkapkan banyak informasi perusahaan telah menerapkan prinsip-prinsip manajemen perusahaan yang baik. Dari uraian diatas disimpulkan bahwa ukuran perusahaan merupakan besarnya jumlah aset yang dimiliki oleh sebuah perusahaan yang menggambarkan tinggi rendahnya kegiatan operasional perusahaan. Semakin besar ukuran perusahaan berarti semakin banyak jumlah aset yang dimiliki oleh perusahaan tersebut. Jadi perusahaan besar umumnya mempunyai total aktiva yang besar pula dan sebaliknya apabila perusahaan kecil umumnya memiliki total aktiva yang kecil.

Hasil penelitian yang dilakukan oleh Amelia (2017) memperoleh hasil bahwa ukuran perusahaan berpengaruh positif terhadap pengungkapan aset biologis. Sejalan dengan hasil penelitian Amelia hasil penelitian Duwu, dkk (2018) menunjukkan bahwa ukuran perusahaan berpengaruh positif terhadap pengungkapan aset biologis.

$\mathrm{H}_{2}$ : Ukuran Perusahaan Berpengaruh Positif Terhadap Pengungkapan Aset Biologis

\section{Pengaruh Kepemilikan Manajerial terhadap Pengungkapan Aset Biologis}

Sonya dan Majid (2016) menyatakan bahwa kepemilikan manajerial adalah pemegang saham dari pihak manajemen yang secara aktif ikut dalam pengambilan keputusan di dalam perusahaan, msalnya direktur dan komisaris. Riski, dkk (2019) dalam jurnalnya menyimpulkan bahwa konsentrasi kepemilikan merupakan sekelompok pengendali atas aktivitas bisnis perusahaan. Hasil penelitian tersebut menunjukkan bahwa kepemilikan manajerial berpengaruh positif terhadap pengungkapan aset biologis. Sedangkan menurut Duwu, dkk (2018) dalam penelitiannya menyatakan bahwa konsentrasi kepemilikan/kepemilikan manajerial adalah suatu ukuran atas distribusi kekuasaan pengambilan keputusan (voting power distribution) baik untuk para pemilik atau para manajer.

Dari uraian diatas menyimpulkan bahwa kepemilikan manajerial adalah kondisi dimana manajer selaku pengendali perusahaan memiliki saham atau dengan kata lain sekaligus berperan sebagai pemegang saham. Alfiani \& Rahmawati (2019) dalam penelitiannya memperoleh hasil bahwa kepemilikan manajerial berpengaruh positif terhadap pengungkapan aset biologis. Sejalan dengan penelitian Alfiani, hasil penelitian Duwu, dkk (2018) juga memperoleh hasil bahwa kepemilikan manajerial berpengaruh positif terhadap pengungkapan aset biologis. 
$\mathrm{H}_{3}$ : Kepemilikan Manajerial Berpengaruh Positif Terhadap Pengungkapan Aset Biologis

\section{METODE PENELITIAN}

\section{Populasi dan Sampel}

Objek penelitian ini menggunakan Perusahaan Sektor Agrikultur sub sektor perkebunan yang terdaftar di Busa Efek Indonesia Periode 2015-2019. Teknik penentuan sampel yang digunakan dalam penelitian ini adalah purposive sampling. Jumlah perusahaan perkebunan yang berjumlah 18 perusahaan dikurangi dengan tidak adanya laporan keangan yang lengkap sebanyak 7 perusahaan dan tidak adanya data kepemilikan manajerial sebanyak 3 perusahaan maka jumlah perusahaan yang menjadi sampel penelitian ini adalah 8 perusahaan. Periode pengamatan yang digunakan adalah dari tahun 2015 sampai dengan 2019 atau selama 5 (lima) tahun sehingga jumlah data yang digunakan adalah sebanyak 40 data. Menururt (Eksandy, 2018) penelitian asosiatif adalah penelitian yang berusaha mencari hubungan antara satu variabel dengan variabel lain. Teknik sampling merupakan teknik pengambilan sampel. Untuk menentukan sampel yang akan digunakan dalam penelitian, terdapat berbagai teknik sampling yang digunakan. Teknik penentuan sampel yang digunakan dalam penelitian ini adalah purposive sampling. Data yang digunakan dalam penelitian ini adalah data sekunder. Data-data yang digunakan dalam penelitian ini diperoleh dari laporan tahunan perusahaan perkebunan listing di Bursa Efek Indonesia selama periode 2015-2019, yang diperoleh dari website Bursa Efek Indonesia. Teknik pengumpulan data dalam penelitian ini adalah menggunakan metode dokumenter yaitu dengan cara pengumpulan data-data dokumen berupa laporan keuangan perusahaan perkebunan yang dimuat dalam IDX. Selain metode dokumenter, penelitian ini menggunakan penelitian kepustakaan (library research), yaitu dengan mengumpulkan datadata dari sumber-sumber pustaka yang mendukung penelitian ini.

\section{Metode Analisis Data}

Menurut (Sugiyono, 2017) Statistik deskriptif adalah statistik yang digunakan untuk menganalisis data dengan cara mendeskripsikan atau menggambarkan data yang telah terkumpul sebagaimana adanya tanpa bermaksud membuat kesimpulan yang berlaku untuk umum atau generalisasi. Analisis statistik deskriptif diatas dihitung dari masing-masing sampel yang ada dan digunakan untuk mengetahui gambaran umum tentang apa saja yang mempengaruhi perusahaan yang melakukan pengungkapan aset biologis. Dalam mengestimasi model regresi dengan menggunakan data panel terdapat tiga pendekatan yang dapat digunakan yaitu ordinary least square (OLS) atau common effect model, model efek tetap (fixed effect model) dan metode efek random (random effect model) (Basuki, 2016)

\section{HASIL DAN PEMBAHASAN \\ Analisis Statistik Deskriptif}

Sebelum menganalisis lebih lanjut estimasi pengaruh Biological Asset Intensity, Ukuran Perusahaan, Kepemilikan Manajerial dan Tingkat Internasionalisasi terhadap Pengungkapan Aset Biologis. Maka perlu diuraikan terlebih dahulu deskripsi data masing-masing variabel yang digunakan dalam penelitian ini. Deskripsi data statistik seluruh variabel yang digunakan dalam penelitian ini sebagai berikut:

Tabel 1 Statistik Deskriptif Perusahaan

\begin{tabular}{|l|c|c|c|c|}
\hline & PAB & BAI & SIZE & KM \\
\hline Mean & 0.325010 & 0.340050 & 29.91625 & 0.211380 \\
\hline Maximum & 0.555600 & 0.869100 & 31.19000 & 0.875300 \\
\hline Minimum & 0.111100 & 0.001600 & 28.30000 & 0.003600 \\
\hline Std. Dev. & 0.115354 & 0.220658 & 0.772229 & 0.285350 \\
\hline Jarque-Bera & 0.520133 & 1.445323 & 1.383347 & 16.98922 \\
\hline Probability & 0.771000 & 0.485459 & 0.500737 & 0.000205 \\
\hline Observations & 40 & 40 & 40 & 40 \\
\hline
\end{tabular}

Sumber: Output Eviews 9.0

Pada tabel 1 diatas, dapat dijelaskan bahwa jumlah data (observations) yang digunakan dalam penelitian ini adalah sebanyak 40 data. Mean adalah rata-rata data, diperoleh dengan menjumlahkan seluruh data dan membaginya dengan cacah data (Eksandy, 
2018)). Nilai mean terbesar dialami oleh variabel ukuran perusahaan (size) yaitu sebesar 29.91625, sementara nilai mean terkecil dialami oleh variabel Kepemilikan Manajerial yaitu sebesar 0.211380. Maximum adalah nilai paling besar dari data (Eksandy, 2018). Nilai maximum terbesar dialami oleh variabel Ukuran Perusahaan (size) yaitu sebesar 31.19000, sementara nilai maximum terkecil dialami variabel Pengungkapan Aset Biologis yaitu sebesar 0.555600. Minimum adalah nilai paling kecil dari data (Eksandy, 2018). Nilai minimum terbesar dialami oleh variabel Ukuran Perusahaan (size) yaitu sebesar 28.30000, sedangkan nilai minimum terkecil dialami variabel Kepemilikan Manajerial yaitu sebesar 0.003600 .

Pengujian terhadap hipotesis penelitian menggunakan analisis regresi data panel. Uji regresi data panel berfungsi untuk menjelaskan hubungan antara variabel bebas dan terikat yang di interprestasikan melalui suatu persamaan yang telah dibuat. Hasil perhitungan analisis regresi data panel dilakukan dengan program eviews 9,2020. Seperti yang ditampilakan pada tabel 1 .

Tabel 2. Rangkuman Hasil Analisis Regresi Data Panel

\begin{tabular}{|l|c|c|c|}
\hline \multicolumn{1}{|c|}{ Hipotesis } & $\begin{array}{r}\text { Nilai (t- } \\
\text { statistik) }\end{array}$ & Sign. & Ket \\
\hline Constant & -2.407170 & 0.0213 & - \\
\hline $\begin{array}{l}\text { Biological Asset Intensity } \\
\text { (H1) }\end{array}$ & 3.152166 & 0.0033 & Diterima \\
\hline $\begin{array}{l}\text { Ukuran Perusahaan } \\
\text { (H2) }\end{array}$ & 2.772290 & 0.0088 & Diterima \\
\hline $\begin{array}{l}\text { Kepemilikan Manajerial } \\
\text { (H3) }\end{array}$ & -1.055051 & 0.2984 & Ditolak \\
\hline $\begin{array}{l}\text { Adjusted R- } \\
\text { Squared }\end{array}$ & \multicolumn{3}{|c|}{0.222822} \\
\hline $\begin{array}{l}|c| \\
\text { Ftatistik }\end{array}$ & \multicolumn{3}{|c|}{} \\
\hline
\end{tabular}

Sumber: Data diolah Eviews 9, 2020

\section{Pengaruh Biological Asset Intensity Terhadap PAB}

Hasil analisis untuk variabel Biological Asset Intensity memiliki nilai t-statistic Biological Asset Intensity sebesar 3.152166, sementara $\mathrm{t}$ Tabel dengan tingkat $\alpha=5 \%$, df $(\mathrm{n}-\mathrm{k})=35$ didapat nilai $\mathrm{t}$ Tabel sebesar 2.03011. Dengan demikian t-statistic BAI $3.152166>\mathrm{t}$ Tabel 2.03011 dan nilai Prob. $0.0033<0.05$. Hasil ini mengidentifikasikan bahwa Biological Asset Intensity secara empiris berpengaruh positif terhadap Pengungkapan Aset Biologis.

Menurut Duwu (2018) dalam penelitiannya, biological asset intensity (intensitas aset biologis) menggambarkan seberapa besar proporsi investasi perusahaan terhadap aset biologis yang dimiliki. Intensitas aset biologis juga mampu menggambarkan ekpektasi kas yang akan diterima jika aset tersebut kemudian dijual. Artinya semakin tinggi intensitas aset biologis perusahaan, maka semakin besar juga dorongan untuk mengungkapkan informasi yang lebih lengkap dan rinci terkait aset biologis yang dimilikinya. Hal ini merupakan bentuk pelaporan perusahaan agrikultur atas aset utama yang dimiliki dan dikelola serta merupakan sumber laba bagi perusahaanperusahaan pada sektor agrikultur. Hasil penelitian Yurniwati,dkk (2018) menunjukkan hasil bahwa biological asset intensity berpengaruh positif terhadap pengungkapan aset biologis, sedangkan pada penelitian Sa'diyah,dkk (2019), menunjukkan hasil yang berbeda bahwa biological asset intensity berpengaruh negatif signifikan terhadap pengungkapan aset biologis.

\section{Pengaruh Ukuran Perusahaan Terhadap PAB}

Hasil analisis untuk variabel Ukuran Perusahaan memiliki t-statistic sebesar 2.772290 sementara $\mathrm{t}$ Tabel dengan tingkat $\alpha=$ $5 \%$, df $(\mathrm{n}-\mathrm{k})=35$ didapat nilai $\mathrm{t}$ Tabel sebesar 2.03011. Dengan demikian t-statistic Ukuran Perusahaan $2.772290>\mathrm{t}$ Tabel 2.03011 dan nilai Prob $0.0088<0.05$. Hasil ini mengidentifikasikan bahwa Ukuran Perusahaan secara empiris berpengaruh positif terhadap Pengungkapan Aset Biologis.

Putri \& Siregar (2019) semakin besar perusahaan semkain dituntut untuk lebih banyak mengungkapkan aset biologis yang ada di dalam perusahaannya. Artinya, semakin besar ukuran perusahaan maka perusahaan 
cenderung akan lebih banyak mengungkapkan aset biologis yang ada di dalamnya. Sehingga pengungkapan informasi yang lengkap dan rinci diperlukan oleh para pemangku kepentingan karena dengan mengungkapkan banyak informasi perusahaan telah menerapkan prinsip-prinsip manajemen perusahaan yang baik. Hasil penelitian yang dilakukan oleh Amelia (2017) memperoleh hasil bahwa ukuran perusahaan berpengaruh positif terhadap pengungkapan aset biologis. Namun hasil penelitian Sa'diyah,dkk (2019) memperoleh hasil bahwa ukuran perusahaan tidak berengaruh terhadap pengungkapan aset biologis.

\section{Pengaruh Kepemilikan Manajerial Terhadap PAB}

Hasil analisis untuk variabel Kepemilikan Manajerial memiliki t-statistic sebesar -1.055051 < t Tabel 2.05954 dan nilai Prob. $0.2984>0.05$. Hasil ini mengidentifikasikan bahwa Kepemilikan Manajerial secara empiris tidak berpengaruh positif terhadap Pengungkapan Aset Biologis. Menurut Duwu, dkk (2018) dalam penelitiannya menyatakan bahwa konsentrasi kepemilikan/kepemilikan manajerial adalah suatu ukuran atas distribusi kekuasaan pengambilan keputusan (voting power distribution) baik untuk para pemilik atau para manajer. Alfiani \& Rahmawati (2019) dalam penelitiannya memperoleh hasil bahwa kepemilikan manajerial berpengaruh positif terhadap pengungkapan aset biologis. Sedangkan penelitian Duwu, dkk (2018) dan Putri, dkk (2019) menunjukkan hasil yang belawanan yaitu tidak berpengaruh terhadap pengungkapan aset biologis.

\section{KESIMPULAN}

Penelitian ini bertujuan untuk membuktikan secara empiris pengaruh Biological Asset Intensity, Ukuran Perusahaan dan Kepemilikan Manajerial terhadap Pengungkapan Aset Biologis. Sampel yang digunakan dalam penelitian ini adalah sebanyak 8 perusahaan sektor Agrikultur sub sektor Perkebunan yang terdaftar di Bursa Efek Indonesia periode 2015-2019. Biological Asset Intensity yang diukur dengan Rasio terbukti secara empiris berpengaruh positif terhadap Pengungkapan Aset Biologis. Hal ini dibuktikan dengan hasil uji t, yang menunjukkan nilai t Tabel sebesar 2.03011. Dengan demikian t-statistic BAI 3.152166 > t Tabel 2.03011 dan nilai Prob. $0.0033<0.05$. Maka berdasarkan hasil tersebut dapat disimpulkan bahwa $\mathrm{H}_{\mathrm{a}}$ diterima, yang artinya $\mathrm{H}_{1}$ memiliki pengaruh. Ukuran Perusahaan yang diukur dengan Rasio terbukti secara empiris berpengaruh positif terhadap Pengungkapan Aset Biologis. Hal ini dibuktikan dengan hasil uji $t$, yang menunjukkan nilai t Tabel sebesar 2.03011. Dengan demikian t-statistic Ukuran Perusahaan $2.772290>$ t Tabel 2.03011 dan nilai Prob $0.0088<0.05$. Maka berdasarkan hasil tersebut dapat disimpulkan bahwa $\mathrm{H}_{\mathrm{a}}$ diterima, yang artinya $\mathrm{H}_{2}$ memiliki pengaruh. Kepemilikan Manajerial yang diukur dengan Rasio terbukti secara empiris tidak berpengaruh terhadap Pengungkapan Aset Biologis. Hal ini dibuktikan dengan hasil uji $\mathrm{t}$, yang menunjukkan nilai $\mathrm{t}$ Tabel sebesar 2.03011. Dengan demikian t-statistic sebesar $1.055051<\mathrm{t}$ Tabel 2.05954 dan nilai Prob. $0.2984>0.05$. Maka berdasarkan hasil tersebut dapat disimpulkan bahwa $\mathrm{H}_{\mathrm{O}}$ diterima, yang artinya $\mathrm{H}_{3}$ tidak berpengaruh.

Penelitian ini memiliki banyak kekurangan dan keterbatasan. Periode penelitian ini relatif singkat hanya 5 (lima) tahun pengamatan, yaitu selama periode 20152019 dan sampel yang terpilih hanya 8 perusahaan dari 16 populasi perusahaan perkebunan yang menjadi sampel penelitian. Berdasarkan hasil perhitungan pada tabel 4.22 hasil Adjusted R-squared menunjukkan bahwa nilai koefisien determinasi R2 sebesar 0.222822 , artinya bahwa variasi perubahan naik turunnya Pengungkapan Aset Biologis dapat dijelaskan oleh Biological Asset Intensity, Ukuran Perusahaan dan Kepemilikan Manajerial hanya sebesar $22,28 \%$ sementara sisanya yaitu $(100 \%$ $22,28 \%$ ) sebesar $77,72 \%$ dijelaskan oleh variabel-variabel lain yang tidak diteliti dalam penelitian ini. 


\section{DAFTAR PUSTAKA}

Alfiani, Linda Kurnia \& Evi Rahmawati. (2019).Pengaruh Biological Asset Intensity, Ukuran Perusahaan, Pertumbuhan Perusahaan, Konsentrasi Kepemilikan Manajerial, dan Jenis KAP Terhadap Pengungkpan Aset Biologis (Pada Perusahaan Agrikultur yang Terdaftar di Bursa Efek Indonesia Periode 2014-2017) ." Reviu Akuntansi dan Bisnis Indonesia, Vol. 3 No. 2, 163-178.

Amelia, Frida. (2017). Pengaruh Biological Asset Intensity, Ukuran Perusahaan, Kepemilikan Manajerial dan Jenis KAP Terhadap Pengungkapan Aset Biologis(Pada Perusahaan Perkebunan yang Terdaftar Di BEI Periode 20122015).

Amelia, Frida. (2017). Pengaruh Biological Asset Intensity, Ukuran Perusahaan, Kepemilikan Manajerial dan Jenis KAP Terhadap Pengungkapan Aset Biologis(Pada Perusahaan Perkebunan yang Terdaftar Di BEI Periode 2012-2015)

Andriyani, Riyan \& Rina Mudjiyanti. (2017). Pengaruh Tingkat Profitabilitas, Leverage, Jumlah Dewan Komisaris Independen dan Kepemiikan Institusional Terhadap Pebgungkapan Internet Financial Reporting (IFR) di Bursa Efek Indonesia. Kompartemen, Vol XV No. 1.

Basuki, Agus Tri \& Nano Prawoto. (2016). Analisis Regresi dalam Penelitian Ekonomi \& Bisnis: Dilengkapi Aplikasi SPSS \& EVIEWS. Depok: PT Rajagrafindo Persada.

-. (2016). Analisis Regresi dalam Penelitian Ekonomi \& Bisnis: Dilengkapi Aplikasi SPSS \& EVIEWS. Depok: PT Rajagrafindo Persada.

Dirvi Surya Abbas, Arry Eksandy. (2020). The Effect Of Effective Tax Rate, Tunneling Incentive, And Exchange Rate On Company Decisions To Transfer Pricing : Food And Consumption Sub-Sector Companies Listed On The Indonesia Evidence. Palarch's Journal Of Archaeology Of Egypt / Egyptology, 17(7), 14430-14442. Retrieved From Https://Archives.Palarch.N1/Index.Php/Jae /Article/View/5486

Duwu, Marselina Inggrid, Sylvia Christina Daat, \& Hastutie N. Andriati. (2018). Pengaruh Biological Asset Intensity, Ukuran
Perusahaan, Konsentrasi Kepemilikan, Jenis Kap, Dan Profitabilitas Terhadap Biological Asset Disclosure .Jurnal Akuntansi \& Keuangan Daerah Volume 13, Nomor 2, 56-75.

Eksandy, Arry. (2018). Metode Penelitian Akuntansi dan Manajemen. Tangerang: FEB UMT.

Ghozali. (2016). Aplikasi Analisis Multivariete dengan Program IBM SPSS 23 (VIII). Semarang: Universitas Diponegoro.

Hariyanti, Anies Indah \& Nur Wijayanti. (2018). Analisis Perbandingan Perlakuan Akuntansi Aset Biologis Berdasarkan International Accounting Standard 41 Dan Pernyataan Standar Akuntansi Keuangan 69 Pada Perusahaan Perkebunan Yang Terdaftar Di Bursa Efek Indonesia. Prosiding Seminar Nasional dan Call for Papers Pengembangan Sumber Daya Perdesaan dan Kearifan Lokal Berkelanjutan VIII 14 - 15 November 201 8 Purwokerto No. ISBN: 978 - 602 - 1643 - 617.

Hartono, Jogiyanto. (2015). Teori Portofolio dan Analisis Investasi Edisi Kelima . Jakarta: Rajawali Pers.

Kirana, Talia Sandra. (2019). Accounting Treatment Of Biological Assets Sugarcane Based On Psak 69 At Pt Perkebunan Nusantara X Surabaya. Artikel Ilmiah.

Kurniahayati, Vanica Serly. (2020). Pengaruh biological asset intensity,Growth,Leverage, Dan tingkat internasional terhadap pengungkapan aset Biologis . Jurnal Eksplorasi Akuntansi Vol.2, No 2, Seri A, 2638-2658.

Munsaidah, Siti, Rita Andini, Agus Supriyanto. (2016). Analisis Pengaruh Firm Size, Profitabilitas, Leverage, dan Growth Perusahaan Terhadap Corporate Social Responsibility ." Journal of Accounting, Vol 2.

Putri, Monica Okri \& Nolita Yeni Siregar. (2019). Pengaruh Biological Asset Intensity, Ukuran Perusahaan, Kepemilikan Manajerial, Dan Jenis Kap Terhadap Pengungkapan Aset Biologis." Jurnal Akuntansi \& Keuangan Vol. 10, No. 2, 4470.

Pracihara, Sonya Majid. (2016). Pengaruh Kebijakan Hutang, Kepemilikan Manajerial, Kebijakan Dividen, dan Ukuran Perusahaan Terhadap Nilai Perusahaan (Studi pada Sektor 
Pertambangan yang Terdaftar di BEI Periode 2011-2014). Jurnal Ilmu Manajemen E-ISSN : 2549-192X, Vol 4 No 2.

Pramitasari, Ratih Koes Dwi. (2018). Pengaruh Faktor Firm Level Terhadap Pengungkapan Aset Biologis Pada Perusahaan Perkebunan Terdaftar di BEI Tahun 2012-2016.

Riski, Tiara, Diyah Probowulan, Retno Murwanti. (2019). Dampak Ukuran Perusahaan, Konsentrasi Kepemilikan Dan Profitabilitas Terhadap Pengungkapan Aset Biologis, $\mathrm{Vol} 8 \mathrm{No} 1$.

Rokhlinasari, Sri. (2016). Teori-Teori dalam Pengungkapan Informasi Corporate Social Responsibility Perbankan. Al-Amwal : Jurnal Ekonomi dan Perbankan Syari'ah.

Sa'diyah, Lentina Diah Jamilatus, Muhaimin Dimyati, \& Wahyuning Murniati. (2019). Pengaruh Biological Asset Intensity, Ukuran Perusahaan, dan Tingkat Internasionalisasi Terhadap Pengungkapan Aset Biologis (Pada Perusahaan Agrikultur Yang Terdaftar Di Bursa Efek Indonesia Periode 2013-2017), 2622-3031.

Sebrina, Usi Gustria \& Nurzi. (2020). Pengaruh Profitabilitas, Ukuran Perusahaan, dan Jenis KAP Terhadap Pengungkapan Aset Biologis. Journal Eksplorasi Akuntansi Vol 2, No 1, 2362-2372.

Sugiyono. (2017). Metode Penelitian Kuantitatif Kualitatif dan $R \& D$. Bandung: Alfabeta.

- (2014). Metode Penelitian Pendidikan Pendekatan Kualitatif, Kuantitatif dan $R \& D$. Bandung: Alfabeta.

Yurniwati, Amsal Djunid,Frida Amelia. (2018). Effect Of Biological Asset Intensity, Company Size, Ownership Concentration, and Type Firm against Biological Assets. The Indonesian Journal of Accounting Research 21 (1). 